\title{
Expression profiles of 11 candidate genes in- volved in drought tolerance of pedunculate oak (Quercus robur L.). Possibilities for genetic monitoring of the species.
}

\author{
Branislav Trudić ${ }^{*}$, Gordon Draškić2* ${ }^{*}$, Gregoire Le Provost ${ }^{3}$, Srđan Stojnić ${ }^{4}$, Andrej Pilipović4 \\ Aleksandar Ivezić 5 \\ * These authors contributed equally to this work and thus share the first authorship \\ ${ }^{1}$ Forest Resource Management Team, Forestry division, Food and Agriculture Organization of the United Nations, Viale \\ delle Terme di Caracalla, 00153 Rome, Italy \\ 2 Persida Inc., A Specialized Software Solutions Provider, 1180 46th street Brooklyn 11219, NY, United States \\ 3 Univ. Bordeaux, INRAE, BIOGECO, F-33610 Cestas, France \\ ${ }^{4}$ Institute of Lowland Forestry and Environment, University of Novi Sad, Antona Čehova 13d, 21000 Novi Sad, Serbia \\ ${ }^{5}$ Forecasting and Warning Service of Plant Protection in Serbia, Temerinska ulica, Novi Sad 131, Serbia \\ * Corresponding author: Branislav Trudic, E-mail: branislav.trudic@fao.org
}

\begin{abstract}
Pedunculate oak (Quercus robur L.) is one of the most significant broadleaved tree species in Europe. However, various abiotic and biotic agents have influenced pedunculate oak forests, among which drought stress has been frequently described as the main driver of this species forests decline. In this study we assessed relative expression profile of 11 candidate genes involved in many different metabolic pathways and potentially responsible for oak drought tolerance. The obtained results succeed in partially tackling drought tolerance mechanisms of targeted natural pedunculated oak population. This gene pool may represent a base for adaptation and therefore genetic diversity should be conserved. In this paper we described different expression responses of four pedunculate oak ecological groups, characterized by different physiological status (senescent vs vital) and flowering period (early (var. praecox) vs late (var. tardissima)). The most significant differences in relative gene expression levels are shown between the flowering period (tardissima (8 genes upregulated) vs praecox (3 genes upregulated)), more than a physiological status (senescent vs vital). Only three genes wrky53, rd22 and sag21 showed upregulated expression pattern in senescent physiological groups, indicating their possible role in the coping mechanisms of oak in stressed environment. Results showed interesting connections of relative gene expression values of
\end{abstract}

identified drought-tolerance related genes with flowering period and provide further recommendations for adequate conservation and monitoring of this important oak gene pool in its southeast refugium.

Keywords: adaptation, drought, gene expression, pedunculate oak, $q P C R$

\section{Introduction}

General projections for climate changes are that they will intensify in the near future, with emphasis on the intensity and frequency of climate extremes (e.g. drought, temperature, precipitation) (IPCC, 2021). It is thus important to understand how plants respond to climate, especially forest tree species which are sessile organisms directly influenced by various abiotic and biotic stressors. A suite of functional traits affect water relationships, resource acquisition and other aspects of plant function (Manzoni, 2014) mediates vegetation responses to environmental conditions. For instance, drought tolerance and water use efficiency of trees can be significantly affected by genetic and environmental background and their interaction (Voelker et al., 2014; Pilipović et al., 2020), but still little is known about 
molecular mechanisms involved in these traits (Trudić et al., 2012).

Temperate oaks represent one of the major components of the European broadleaved forest resources with high economic and ecological importance, contributing greatly to the social and economic well-being of the populations (Varela, 1995; Ducousso, A., and Bordacs, S, 2003). The regeneration of pedunculate oak in Serbia is based on the shelterwood cutting system in large areas, where the understory layer and trees of the previous stand are removed in several phases in short regeneration periods (2-3 years), through the preparatory, regeneration and final cuts. However, even though present management models give good results, changes and improvements are needed considering the presence of multiple biotic (pest and diseases) and abiotic factors (e.g. drought stress) that have negative influence on the survival and development of pedunculate oak forests (Rađević et al., 2020). Marker assisted genetic analyses of pedunculated oak in Serbia, which is the south-eastern refugium, showed presence of conserved heterozygosity (Trudić et al., 2021), meaning that forest management keeps good selection practices in this area allowing sustainability of the gene pool.

Abiotic stresses are major causes of loss of forest production and natural vegetation because they cause many morphological, physiological, biochemical and molecular changes that affect plant growth and productivity (Trudić et al., 2012). Arend et al. (2013) recorded significantly higher metabolic sensitivity to drought stress in Quercus robur, compared to two other common oak species in Western Balkans (Q. petrea and Q. cerris), which makes pedunculate oak an interesting study area for further adaptability research. Indeed, other studies evidenced large intraspecific variability of intrinsic water-use efficiency (WUEi) in Q. robur (Ponton et al., 2002), as well as high contribution of certain leaf stomatal traits in driving WUEi diversity on a species level (Roussel et al., 2009; Stojnić et al., 2019a), further indicating that this parameter might be efficiently used in breeding programs as a suitable indicator of $Q$. robur drought sensitivity. Knowledge about, and "management" of abiotic stresses are especially important for long-term growth and survival of woody plant species worldwide. Adaptation of plants to stress from the environment is mediated by a series of highly coordinated and complex signaling pathways. Stress-sensing mechanisms regulate different cellular and molecular events in plants and the expression of various stress-tolerant genes (Trudić et al., 2013). Pilipović et al. (2020) conducted a study of the influence of simulated drought on the pedunculate oak seedlings, measuring net photosynthesis, stomatal conductance and chlorophyll content. Results showed that there was a significant genetic effect in relation to the seedlings response to induced stress and recovery, indicating the possibility to use physiological parameters in the selection of stress-tolerant oak progenies and provenances.

One of the ways plants react to abiotic stress is a change in the expression of the corresponding genes (Trudić et al., 2012). Products from the activities of these genes can be divided into two groups: 1) regulators of gene expression and signaling pathways (e.g. protein kinases, phosphatases, transcription factors, etc.), and 2) functional molecules that are directly involved in tolerance to stress, such as various antioxidants, chaperones, osmotic protectants, etc. (Trudić et al., 2013).

Large collections of oak expressed sequence tags (ESTs) have been generated from various tissues and developmental stages, including 130,000 Sanger sequences and approximately 2.5 million reads available from public databases (Ueno et al., 2010). This catalog constitutes a useful resource for detecting candidate genes controlling traits of interest for the development of new genetic markers for genetic approaches (linkage mapping and QTL detection, association mapping) or for dissection of genetic architecture of adaptive traits (Alberto et al., 2010; Casasoli et al., 2006; Derory et al., 2010; Durand. et al., 2010; Leroy et al., 2020). Additionally, the reference genome of pedunculate oak is now available and anchored to a genetic map, which makes it easier to identify genes that matter the most for adaptation of this species (Plomion et al., 2018).

Taking into consideration the importance of pedunculate oak gene pool for local, national and regional biodiversity and mitigation of climate change, profound importance is addressed to genetic diversity research within ex situ and in situ conservation efforts (Stojnić et al., 2019b). In addition, breeding of more resilient provenances represents one of the efficient ways for future adaptation that will enable plants to optimize their life processes in prevailing environmental conditions on the evolutionary scale (Beikircher and Mayr, 2009). Therefore, the aim of this study was to give the first insight on the molecular mechanism explaining drought tolerance in targeted $Q$. robur population and generate recommendations important for conservation efforts, using relative expression profiles of 11 genes involved in drought stress tolerance in plants.

\section{Material and Methods}

\section{Sampling of specimens}

In order to properly evaluate individuals for further gene expression analysis, we first selected them according to phenophase (early (var. praecox) vs late (var. tardissima)) and physiological groups (vital or senescent), and then we assessed morphometric traits for all of them. The main criterion for determining the affinity of trees to one of the physiological groups (vital or senescent) was the degree of canopy damage, which was assessed by Dubravac et al., (2011): trees with canopy damage above $25 \%$ were considered significantly damaged trees, while trees with canopy damage up to $25 \%$ were considered undamaged or vital trees. Damage caused by pathogens was used as an additional criterion in tree selection. Canopy damage was assessed in the same year as sampling.

Leaf samples from 42 individuals ( 21 individuals of Quercus robur var. praecox (11 vital + 10 senescent) and 21 individuals of $Q$. robur var. tardissima ( 11 vital +10 senescent)) were collected from seed orchard forest located in the Northern part of Serbia ( $\mathrm{N} 45^{\circ} 00^{\prime} 12.66^{\prime \prime} \mathrm{E} 019^{\circ} 08^{\prime} 50.4^{\prime \prime}$ ) during springtime in April and May 2013 (Figure 1). The altitude of the management 
unit was ranging from 81 to $83 \mathrm{~m}$ above sea level (a.s.l.). The geological substrate was defined as alluvial sand sediments with mostly gley soils ranging from riparian black soil and black meadow soil to brown forest soil. Hydrological conditions were characterized by the absence of flooding and soil moisture was strongly dependent on fluctuations of groundwater table levels. The investigated area represents Pannonian environmental zone PAN1 (Metzger et al., 2005). The climate records were obtained from nearby weather station „Sremska Mitrovica" (N 4501"; E 19 $33^{\prime \prime} ; 82 \mathrm{~m}$ a.s.l) for the period 20112013 (Republic Hydrometeorological Service of Serbia 2011, 2012 and 2013) (Supplementary material 1).

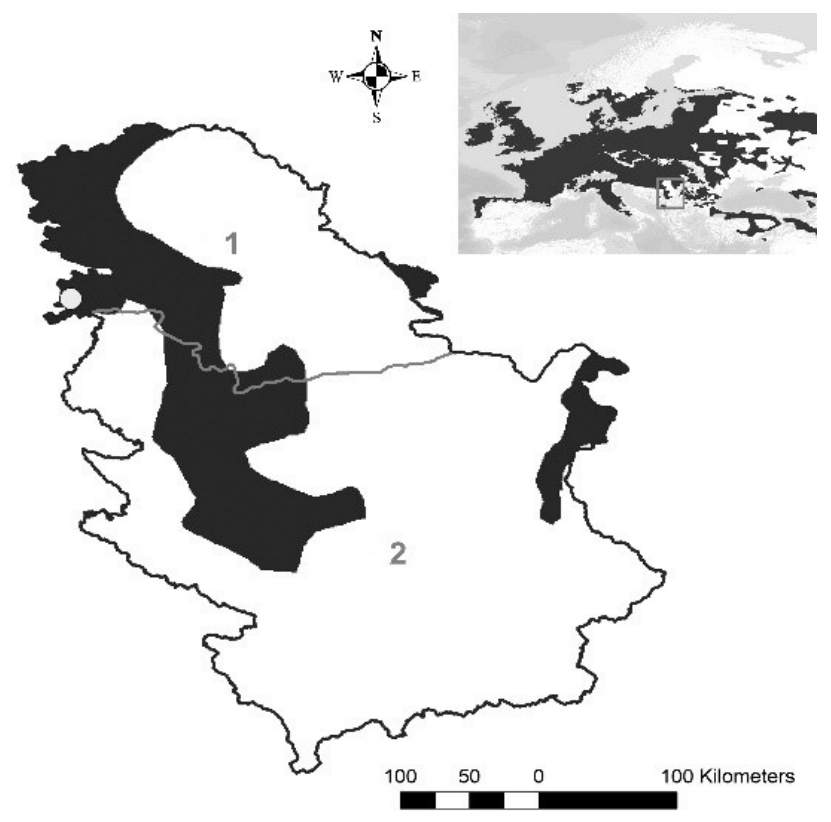

Legend:

- The location of the sampled pedunculate oak population

1 - Posavsko-Podunavski provenance region

2 - Centralna Srbija provenance region

Figure 1

The map of two officially registered regions of pedunculate oak provenances in Serbia regulated by national decision on establishing the regions of pedunculate oak provenances in Serbia: 91/2008-16. Shaded areas represent the distribution range of $Q$. robur in Europe (upper smaller picture) and Serbia (large picture) according to Ducousso, A., and Bordacs, S. (2003). The small white dot in upper left part of the map is marking the location of penduculate oak gene pool covered in this study.

\section{Morphometric analyses}

For all individual trees, diameter at breast height (DBH $[\mathrm{cm}])$, absolute height of trees $(\mathrm{H}[\mathrm{m}])$ and height to the crown $(\mathrm{HC}$ [m]) were performed. DBH was measured with classic caliper (Haglöf, Sweden) whereas $\mathrm{H}$ and HC were measured using "Vertex III" (Haglöf Sweden AB) apparatus. All statistical analyses for morphometric parameters were performed in Statistica version 13 (TIBCO Software Inc. 2017). One-way analysis of variance (ANOVA) was conducted to determine the statistical significance of the four oak ecological groups to (1) $\mathrm{DBH},(2) \mathrm{H}$ and (3) HC. All statistical analyses were performed at $\mathrm{p} \leq 0.05$ level of significance.

\section{DNA extraction, $P C R$ and $q P C R$}

Forty-two fully developed leaf samples were harvested and sent on dry ice via DHL transportation service 24 hours before the start of RNA extraction to BIOGECO laboratories in Bordeaux, Cestas, France. To minimize the variability between individuals as much as possible, we performed extraction independently for 10 senescent and 11 vital individuals separately and then generated three biological replications equimolary for each condition and variety. Total RNA was isolated from samples following the procedure described in Le Provost et al. (2007). The quantity and quality of the RNA were assessed with an Agilent 2100 bioanalyzer (Agilent Technologies, Inc., Santa Clara, CA, USA) after removal of residual genomic DNA with DNAse I enzyme and purification step with RNAeasy RNA clean up protocol by QIAGEN. Process of reverse transcription and construction of CDNA was done by iScript cDNA Synthesis Kit ${ }^{\circ}$ from Bio-Rad Company according to the manufacturer's instructions. Two housekeeping genes (18s with $103 \%$ efficiency and ef $\beta$ with $99 \%$ efficiency) were used to normalize the data and the main criterion for their selection was their stability across biological samples.

Prior to gene primers design in Primer $3^{\circledR}$ software (Rozen and Skaletsky, 2000) a search of gene sequences for Arabidopsis thaliana was done in TAIR database (The Arabidopsis Information Resource, 2015). After that, Blast analysis was performed against oak EST database in order to identify and select orthologues based on their e-value (Table 1 and Table 2).

We checked the specificity of the amplification product using conventional agarose gel electrophoresis and afterwards we performed the quantification. Conventional PCR programs for multibanding quality control check were as follows: initial denaturation at $94^{\circ} \mathrm{C}$ for $5 \mathrm{~min}, 35 \mathrm{cycles}$ at $94^{\circ} \mathrm{C}$ for $30 \mathrm{sec}, 60^{\circ} \mathrm{C}$ for $30 \mathrm{sec}$ and $72^{\circ} \mathrm{C}$ for $30 \mathrm{sec}$, and final extension at $72^{\circ} \mathrm{C}$ for 7 $\min$.

Master mix solution for qPCR for a total of 12 samples was prepared as a mixture of forward and reverse primers (3.6 $\mu \mathrm{l}$ of each, see Table 2.), $\mathrm{mQH}_{2} \mathrm{O}(88.8 \mu \mathrm{l})$ and $\mathrm{Tp}$ IQSyberGreen $(120 \mu l)$. qPCR reaction was run for $18 \mu$ l of Master mix solution with $2 \mu \mathrm{l}$ of cDNA sample, following standardized program for this type of biological samples and reaction: initial denaturation at $95^{\circ} \mathrm{C}$ for $3 \mathrm{~min}, 39 \mathrm{cycles}$ at $95^{\circ} \mathrm{C}$ for $15 \mathrm{sec}, 95^{\circ} \mathrm{C}$ for $45 \mathrm{sec}$; plate read, melting curve from 65 to $95^{\circ} \mathrm{C}$, read every $0.1^{\circ} \mathrm{C}$, hold $1 \mathrm{sec}$ on Chromo4 Continuous Fluorescence Detector Gradient Cycler DNA engine ${ }^{\mathrm{TM}}$ (Chromo4 ${ }^{\mathrm{TM}}$ System - Bio-Rad). A threshold for DNA-based fluorescence detection was set slightly above background and the threshold cycle $\left(C_{t}\right)$ was measured as described in Le Provost et al., 2016.

First, geNorm (https://genorm.cmgg.be/) was used to select the most stable housekeeping genes before qPCR analyses. Mean Ct and their standard deviations were calculated for individual samples and then pooled into four ecological groups: early senescent oak (hereinafter: PEOS), early vital oak (hereinafter: PEOV), late senescent oak (hereinafter: PLOS) and 
Table 1

Candidate genes used for qPCR expression profile determination. Each gene was checked for multibanding pattern through conventional PCR reaction and agarose gel electrophoresis.

\begin{tabular}{|c|c|c|c|c|}
\hline No. & Annotation & Gene & Primer pairs & GenBank accession number \\
\hline 1 & Drought induced gene 21 & atdi21 & $\begin{array}{l}\text { F: ATTTCGAAGCTCGACTGCAT } \\
\text { R: AGAAGATTGTGGGGCCTCTT }\end{array}$ & CR627776 \\
\hline 2 & $\begin{array}{l}\text { AWPM-19-like membrane family } \\
\text { protein }\end{array}$ & awmp & $\begin{array}{l}\text { F: GTTGCTTCATGCTGGGATCT } \\
\text { R: CATAAGGGTGGTGCTCCTGT }\end{array}$ & XM_031067968.1 \\
\hline 3 & $\begin{array}{l}\text { Gibberellin-regulated GASA/GAST/ } \\
\text { Snakin family protein }\end{array}$ & gasa & $\begin{array}{l}\text { F: GATGTATGCCCCTGCTACG } \\
\text { R: ATTGGCTGCATGTGTTGGTA }\end{array}$ & XM_031099810.1 \\
\hline 4 & Basic 7S globulin 2 & globulin & $\begin{array}{l}\text { F: GCCACTGCCATTCCAACTAT } \\
\text { R: AGGAGCGGCATATTTCATTG }\end{array}$ & XM_024060619.1 \\
\hline 5 & Glutathione-s-transferase tau 19 & gst & $\begin{array}{l}\text { F: CGGCGTAGAGGAACGATTAG } \\
\text { R: TGTCCGTTTAGCTTGCAAGA }\end{array}$ & XM_031105862.1 \\
\hline 6 & $\begin{array}{l}\text { Late embryogenesis abundant } \\
\text { protein Lea5 }\end{array}$ & lea & $\begin{array}{l}\text { F: AGAAGATTGTGGGGCCTCTT } \\
\text { R: ATGCAGTCGAGCTTCGAAAT }\end{array}$ & XM_031068332.1 \\
\hline 7 & $\begin{array}{l}\text { Dehydration-responsive protein } \\
\text { RD22 precursor }\end{array}$ & $r d 22$ & $\begin{array}{l}\text { F: GCCCAGACAACATGATCCTC } \\
\text { R: CAGAATGGAACCCAAAGCAT }\end{array}$ & FP041436 \\
\hline 8 & Senescence associate gene 21 & sag21 & $\begin{array}{l}\text { F: CTCGTCGACACGATTCTCAG } \\
\text { R: GGTGAAGAAGCAAGGTGAGG }\end{array}$ & XM_031092942.1 \\
\hline 9 & $\begin{array}{l}\text { Gene for transcription factor wrky } \\
\text { involved in defense, wounding and } \\
\text { senescence } 53\end{array}$ & wrky53 & $\begin{array}{l}\text { F: GGGAGCGATGAATTTGAGAA } \\
\text { R: CCCTCACTTGGTCTGTCCAT }\end{array}$ & FN727229 \\
\hline 10 & Dehydrin Xero 2 & xero2 & $\begin{array}{l}\text { F: GCTTTGACACTTGCTTTTGC } \\
\text { R: AAACCAGCAGAAGAAGGGGT }\end{array}$ & AM711636.1 \\
\hline 11 & $\begin{array}{l}\text { Xyloglucan endotransglucosylase/ } \\
\text { hydrolase } 9\end{array}$ & xet2 & $\begin{array}{l}\text { F: TGATCCATGCCTGTTTGGTA } \\
\text { R: AAGTGGTTCTAAACCGCCCT }\end{array}$ & XM_031074399.1 \\
\hline
\end{tabular}

Table 2

Genes used in this study and their role in plant metabolism. Plant organism(s) - organism in which the gene was firstly identified and reported.

\begin{tabular}{|c|c|c|c|}
\hline Gene & Role & Plant organism(s) & Reference \\
\hline atdi21 & $\begin{array}{l}\text { Response to abscisic acid stimulus, response to water deprivation, } \\
\text { response to stress. }\end{array}$ & Arabidopsis thaliana & Aghdasi et al., 2012 \\
\hline awmp & Response to temperature stress. & Gossypium hirsutum & Hsing et al., 1995 \\
\hline gasa & Response to gibberellin stimulus. & Arabidopsis thaliana & Thierry-Mieg et al., 2006. \\
\hline globulin & $\begin{array}{l}\text { Seed storage protein. Response to stress, hormone receptor-like } \\
\text { activity, protein kinase activity. Binds leginsulin. }\end{array}$ & Glycine hispida & Hirano, 2021 \\
\hline gst & $\begin{array}{l}\text { Response to drought stress, oxidative stress, and high doses of auxin } \\
\text { and cytokinin. }\end{array}$ & Arabidopsis thaliana & Wagner et al., 2002 \\
\hline lea & $\begin{array}{l}\text { Response to abiotic stress (dehydration, salinity, high and low tem- } \\
\text { perature). }\end{array}$ & Gossypium hirsutum & Dure et al., 1981 \\
\hline$r d 22$ & $\begin{array}{l}\text { Response to salt stress, response to abscisic acid stimulus, response } \\
\text { to desiccation. }\end{array}$ & Arabidopsis thaliana & Yamaguchi-Shinozaki and Shinozaki, 1993 \\
\hline sag21 & Response to cold, response to oxidative stress, response to stress & Arabidopsis thaliana & Miller et al., 1999 \\
\hline wrky53 & $\begin{array}{l}\text { Defense response to bacterium, incompatible interaction, regulation } \\
\text { of transcription. }\end{array}$ & Arabidopsis thaliana & Murray et al., 2007 \\
\hline xero2 & $\begin{array}{l}\text { Cold acclimation, response to abscisic acid stimulus, response to cold, } \\
\text { response to water deprivation, response to stress. }\end{array}$ & Arabidopsis thaliana & Chung and Parish, 2008 \\
\hline
\end{tabular}


late vital oak (hereinafter: PLOV). All calculations were done in Gene Expression Analysis for iCycler iQ v1.10 ${ }^{\mathrm{TM}}$ from Bio-Rad using calculations derived from the algorithms outlined by Vandesompele et al., (2002). Bar charts were created using matplotlib v3.4.1 package (Caswell et al., 2021) for Python programming language for pooled samples as differences in gene expression between these groups is the main aim of this study. The Python script for the bar chart creation is available on request.

\section{Results}

\section{Morphometric analyses}

The results ANOVA for $\mathrm{DBH}, \mathrm{H}$ and $\mathrm{HC}$ between genotypes with different ecological status are shown in Table 3. No statistically significant differences between ecological types in terms of investigated phenotypic traits were found.
Certain ecological groups of analyzed oak showed high and very high values of standard deviation. This was expected since samples were taken from individuals grown in nature where multifactorial ecological influences on gene expression is present, including the variation of different flowering periods. Higher gene expression was observed within phenological groups (late vs early ones) rather than between physiological conditions (8 genes vs 3 genes). Wrky53 and rd22 clearly showed upregulation pattern within groups identified as senescent, indicating initiative expression during the physiological processes of abiotic stresses, especially cumulative drought. Similarly, Spies et al. (2012) found that genes with protective function such as lea and rci2b had increased transcript levels in Quercus robur under drought stress. Porth et al. (2005) characterized 33 osmotic-stress-induced transcripts from tissue cultures of sympatric species to pedunculate oak, $Q$. petraea.

Table 3

Variance results of diameter at breast height $(\mathrm{DBH}[\mathrm{cm}])$, absolute height of trees $(\mathrm{H}[\mathrm{m}])$ and height to the crown $(\mathrm{HC}[\mathrm{m}])$ between genotypes with different ecological status with $\mathrm{p} \leq 0.05$ level of significance. $\mathrm{df}$ - degrees of freedom; SS - sum of squares; MS - mean square; F - F statistic.

\begin{tabular}{|c|c|c|c|c|c|c|c|c|c|c|c|c|c|}
\hline \multirow{2}{*}{ Effect } & \multirow{2}{*}{ df } & \multicolumn{4}{|c|}{ DBH } & \multicolumn{4}{|c|}{$\mathrm{H}$} & \multicolumn{4}{|c|}{$\mathrm{HC}$} \\
\hline & & SS & MS & $\mathrm{F}$ & $\mathrm{p}$ & SS & MS & $\mathrm{F}$ & $\mathrm{p}$ & SS & MS & $\mathrm{F}$ & $p$ \\
\hline Ecological type & 3 & 218.1 & 72.7 & 0.841 & 0.479 & 86.9 & 28.9 & 2.632 & 0.064 & 24.6 & 8.2 & 1.096 & 0.363 \\
\hline Error & 37 & 3197.7 & 86.4 & & & 407.2 & 11.0 & & & 277.4 & 7.5 & & \\
\hline Total & 40 & 3415.9 & & & & 494.1 & & & & 302.1 & & & \\
\hline
\end{tabular}

\section{Relative gene expression}

Results of descriptive statistics (means and standard deviations) of threshold cycle (Ct) and relative gene expression (RGE) of all genes for each oak category are presented in Table 4 and depicted on Figure 2. Maximum relative gene expression was 7,27 for PLOV for gasa gene, whereas minimum values for relative gene expression were 1,00 for PEOS for awpm and xero2 genes, PEOV for atdi21, gasa, lea, rd22, sag21 and wrky53, and PLOS for globulin, gst and xet genes.

\section{Discussion}

During 2011-2012, a very dry and long summer with higher temperature, strong insolation, lesser amount of available water in the soil and atmosphere, by multifactorial drought, made the environment quite challenging for survival of pedunculate oak forests in the observed area (Stojanović et al., 2015). In this study, we wanted to obtain first insight to differential relative gene expression response to these complex environmental changes.
They also found immediate increase of expression of the badh in response to osmotic stress in Q. petrea species, but the progression of gene expression for badh, Itp and ox2og differed strikingly between $Q$. robur and Q. petraea. Additionally, expression of the badh, which catalyzed the synthesis of the osmoprotective molecule glycine betaine, was down-regulated in $Q$. robur, whereas it was up-regulated in $Q$. petraea (Porth et al., 2005). Expression of the Itp, responsible for formation and reinforcement of plant surface layers, was rather constant in $Q$. robur compared with Q. petraea (Porth et al., 2005). The high expression of Itp in Q. petraea, which is adapted to dry sites, likely reflects species specificity in expression level (Porth et al., 2005). Unfortunately, they did not monitor these gene expression patterns with bud phenology nor any other correlation with it.

Following RGE patterns of wrky53 and rd22, sag21 gene showed similar expression pattern, although the highest value of RGE was shown in late flowering vital group. This mechanism is not surprising since buds are made of dehydrated tissue in order to avoid ice formation from winter frost (Čehulić et al., 2019). Interesting RGE pattern was also found for globulin gene, where significant increase of the expression is shown in 


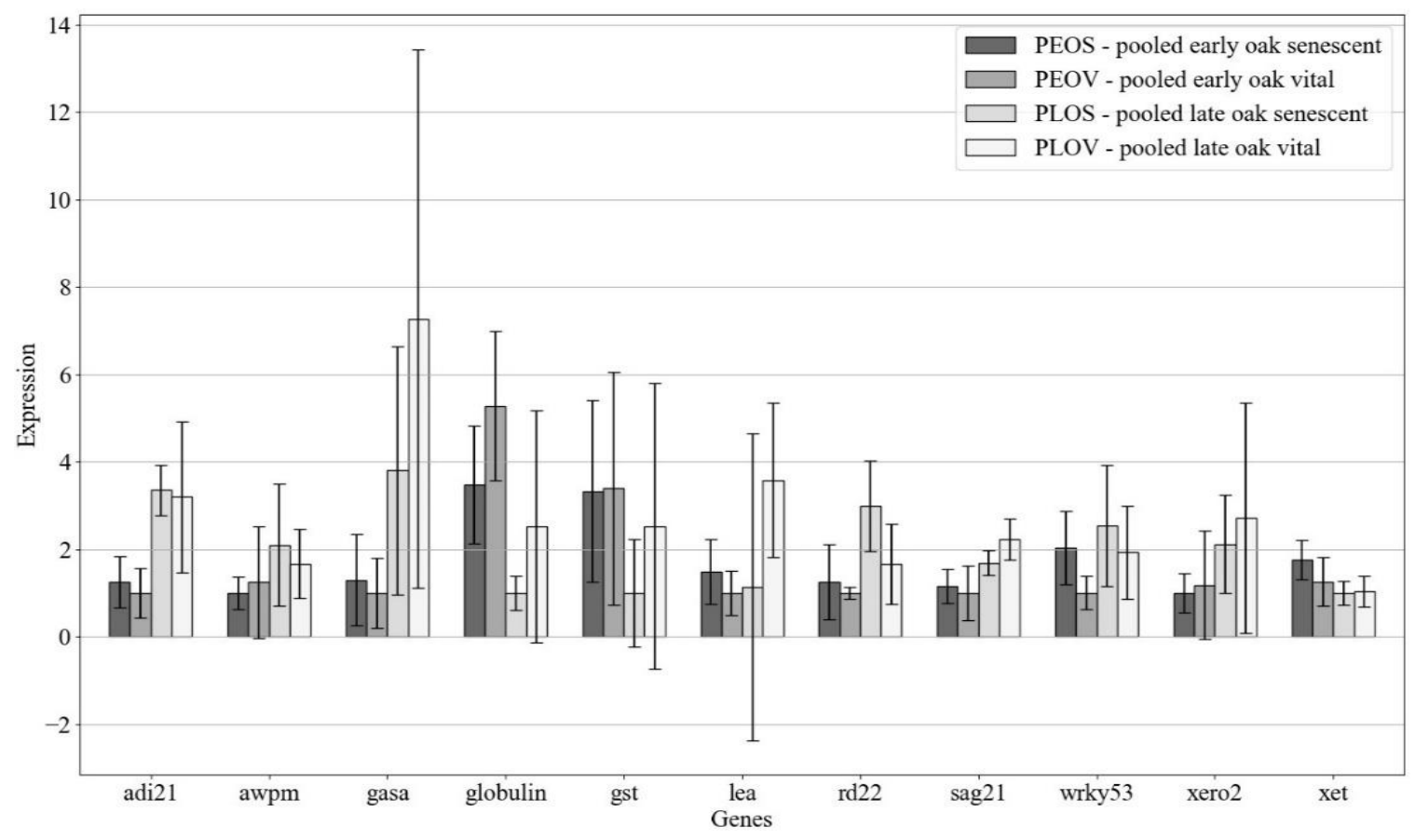

Figure 2

A bar chart of gene expression of 11 genes for four oak categories plotted on $\mathrm{X}$ axis and relative gene expression plotted on $\mathrm{Y}$-axis. The data obtained by quantitative RT-PCR were normalized to the expression of the reference genes ef $\beta$ and $18 \mathrm{~s}$. Error bars indicate standard deviation obtained from three biological replicates. Values are the mean of three technical replicates of independent cDNA synthesis from the same extraction. Pooled representation of all individuals belonging to each ecological group was used to get the insight of gene expression response. See Appendix 2 of supplementary material for bar charts of each individual gene relative expression profile per oak ecological group.

early flowering senescent group whereas this expression significantly decreases in late flowering senescent group. It might be that this gene is active during early flowering phases supporting plants metabolism to cope with the both physiological processes of bud burst and senescence caused by external abiotic stressors. Adi21 gene showed similar high RGE pattern in late flowering senescent group, probably having similar role as globulin but in later flowering periods. These two genes highlight different molecular strategies implemented in the different oak ecological groups to cope with drought stress conditions.

Kotrade et al., (2019) used quantification data from a comparative transcriptome analysis for the selection of candidate reference genes for three oak species (Q. robur, Q. ilex and $Q$. pubescens) for stress transcriptomic analysis and identified novel reference genes for each species (fhy3 for $Q$. robur and at 1954610 for all tree species) that are more stably expressed than classical reference genes. It is therefore expected that by testing a larger set of reference genes, more genes that are highly stably expressed across all oak species could be identified and later used in stress-related studies.

\section{Conclusions}

A more accurate picture on gene expression profiling and metabolic reactions on drought stress should be facilitated with the comparison of our results with the ones where samples were grown in controlled conditions, like seedlings and tissue culture in greenhouse environment. This way, particular gene function can be tackled, and biology of species accurately understood when it comes to the abiotic and biotic stress influence on gene expression pattern. Our goal is to develop such approach in the coming years to target among the chosen candidate genes those that matter for adaptation to drought in oaks.

Although described limitations within the facilitated study do not allow gaining full conclusion on the adaptation of oak to long-term drought exposure in open environment, it is clear that oak trees are capable of adjusting their metabolism for some time, at the cost of a phenotype quality and overall vitality. Also, we registered significant correlation of bud burst phenology with majority of observed genes. Previous studies through literature review showed that $Q$. robur also applies different strategies of drought stress protection depending on the duration and intensity of the stress. It is needed to involve 
Table 4

Mean $C_{t}$ and relative gene expression (RGE) \pm standard deviation (SD) of 11 genes for four analyzed types of oak. PLOS: pooled late oak senescent, PLOV: pooled late oak vital, PEOS: pooled early oak senescent, PEOV: pooled early oak vital. Bolded RGE \pm SD indicate very high values of standard deviations particularly comparing to the value of RGE. Bolded and underlined values are the ones where SD values are higher than the RGE values.

\begin{tabular}{|c|c|c|c|}
\hline Gene & Oak ecological group & $\mathrm{Ct}$ & $\mathrm{RGE} \pm \mathrm{SD}$ \\
\hline \multirow[t]{4}{*}{ adi21 } & PEOS & $21.37 \pm 0.689$ & $1.25 \pm 0.578$ \\
\hline & PEOV & $22.21 \pm 0.860$ & $1.00 \pm 0.559$ \\
\hline & PLOS & $20.20 \pm 0.164$ & $3.35 \pm 0.577$ \\
\hline & PLOV & $20.43 \pm 0.831$ & $3.20 \pm 1.729$ \\
\hline \multirow[t]{4}{*}{ awpm } & PEOS & $23.61 \pm 0.493$ & $1.00 \pm 0.371$ \\
\hline & PEOV & $23.75 \pm 1.461$ & $1.25 \pm 1.278$ \\
\hline & PLOS & $22.89 \pm 0.928$ & $2.10 \pm 1.391$ \\
\hline & PLOV & $23.36 \pm 0.667$ & $1.67 \pm 0.792$ \\
\hline \multirow[t]{4}{*}{ gasa } & PEOS & $23.80 \pm 1.229$ & $1.30 \pm 1.043$ \\
\hline & PEOV & $24.71 \pm 1.240$ & $1.00 \pm 0.800$ \\
\hline & PLOS & $22.50 \pm 1.146$ & $3.80 \pm 2.845$ \\
\hline & PLOV & $21.65 \pm 1.313$ & $7.27 \pm 6.164$ \\
\hline \multirow[t]{4}{*}{ globulin } & PEOS & $24.83 \pm 0.675$ & $3.48 \pm 1.352$ \\
\hline & PEOV & $24.65 \pm 0.580$ & $5.28 \pm 1.704$ \\
\hline & PLOS & $27.60 \pm 0.675$ & $1.00 \pm 0.387$ \\
\hline & PLOV & $26.06 \pm 1.958$ & $2.52 \pm 2.661$ \\
\hline \multirow[t]{4}{*}{ gst } & PEOS & $22.04 \pm 1.008$ & $3.33 \pm 2.084$ \\
\hline & PEOV & $22.53 \pm 1.290$ & $3.39 \pm 2.661$ \\
\hline & PLOS & $24.42 \pm 2.007$ & $1.00 \pm 1.220$ \\
\hline & PLOV & $23.05 \pm 2.131$ & $2.53 \pm 3.271$ \\
\hline \multirow[t]{4}{*}{ lea } & PEOS & $20.76 \pm 0.744$ & $1.48 \pm 0.737$ \\
\hline & PEOV & $21.87 \pm 0.789$ & $1.00 \pm 0.514$ \\
\hline & PLOS & $21.54 \pm 4.783$ & $1.14 \pm 3.515$ \\
\hline & PLOV & $19.92 \pm 0.759$ & $3.58 \pm 1.772$ \\
\hline \multirow[t]{4}{*}{$r d 22$} & PEOS & $19.06 \pm 1.011$ & $1.26 \pm 0.856$ \\
\hline & PEOV & $19.89 \pm 0.145$ & $1.00 \pm 0.129$ \\
\hline & PLOS & $18.11 \pm 0.479$ & $2.99 \pm 1.028$ \\
\hline & PLOV & $19.15 \pm 0.830$ & $1.66 \pm 0.921$ \\
\hline \multirow[t]{4}{*}{$\operatorname{sag} 21$} & PEOS & $20.58 \pm 0.413$ & $1.15 \pm 0.391$ \\
\hline & PEOV & $21.19 \pm 0.823$ & $1.00 \pm 0.625$ \\
\hline & PLOS & $20.38 \pm 0.135$ & $1.69 \pm 0.287$ \\
\hline & PLOV & $20.15 \pm 0.254$ & $2.23 \pm 0.470$ \\
\hline \multirow[t]{4}{*}{ wrky53 } & PEOS & $23.97 \pm 0.595$ & $2.03 \pm 0.840$ \\
\hline & PEOV & $25.53 \pm 0.569$ & $1.00 \pm 0.384$ \\
\hline & PLOS & $23.99 \pm 0.795$ & $2.54 \pm 1.375$ \\
\hline & PLOV & $24.56 \pm 0.823$ & $1.93 \pm 1.060$ \\
\hline \multirow[t]{4}{*}{ xero2 } & PEOS & $21.75 \pm 0.612$ & $1.00 \pm 0.446$ \\
\hline & PEOV & $21.97 \pm 1.515$ & $1.18 \pm 1.243$ \\
\hline & PLOS & $21.01 \pm 0.739$ & $2.12 \pm 1.122$ \\
\hline & PLOV & $20.79 \pm 1.388$ & $2.72 \pm 2.625$ \\
\hline \multirow[t]{4}{*}{ xet } & PEOS & $21.31 \pm 0.307$ & $1.76 \pm 0.445$ \\
\hline & PEOV & $22.24 \pm 0.626$ & $1.26 \pm 0.558$ \\
\hline & PLOS & $22.46 \pm 0.358$ & $1.00 \pm 0.283$ \\
\hline & PLOV & $22.55 \pm 0.470$ & $1.04 \pm 0.352$ \\
\hline
\end{tabular}


larger groups of genes and sample size in order to get precise information on gene expression profiles with multifactorial abiotic stress influence. In case of natural populations, which are under influence of many climatic factors sometimes it is difficult or impossible to measure, continuity and longevity of gene expression monitoring as a part of regular forest genetic monitoring practice is needed.

We recommend establishing continuous, long-term monitoring of ecophysiological parameters (photosynthesis, transpiration, stomatal conductance and other plant water status related parameters) which can be correlated with the expression of particular genes or family of genes directly involved in those and related processes in planta. In terms of further usage of these results in forest genetic monitoring practices of pedunculate oak and related broadleaved species, further principle coordinate analyses of relative gene expression values and other available parameters such as expected and observational heterozygosity, phenotypic measurements, physiological and biochemical measurements are needed. This would make possible to determine which set of parameters is the most reliable in genetic monitoring practice of the species.

\section{Acknowledgement}

This research was conducted under the short-term scientific mission "Drought resistance candidate genes and their expression in the Quercus robur L. species from Srem provenance using qPCR" within COST Action FP 0905: "Biosafety of forest transgenic trees: improving the scientific basis for safe tree development and implementation of EU policy directives." We would like to thank Mr Ed Bauer (retired) from the USDA Forest Service, Northern Research Station, Institute for Applied Ecosystem Studies, Rhinelander, WI USA for English and style editing.

\section{References}

Aghdasi M, Fazli F, Bagherieh MB (2012) Cloning and expression analysis of Arabidopsis TRR14 gene under salt and drought stress. Journal of Cell and Molecular Research 4:1-10. https://doi.org/10.22067/jcmr.v4i1.12269.

Alberto F, Niort J, Derory J, Lepais O, Vitalis R, Galop D, Kremer A (2010) Population differentiation of sessile oak at the altitudinal front of migration in the French Pyrenees. Molecular Ecology 19:2626-2639. https://doi.org/10.1111/j.1365-294X.2010.04631.x

Arend M, Brem A, Kuster TM, Günthardt-Goerg MS (2013) Seasonal photosynthetic responses of European oaks to drought and elevated daytime temperature. Plant Biology 15: 169-176. https://doi.org/10.1111/j.1438-8677.2012.00625.x

Beikircher B, Mayr S (2009) Intraspecific differences in drought tolerance and acclimation in hydraulics of Ligustrum vulgare and Viburnum lantana. Tree Physiology 29(6): 765-775. https://dx.doi.org/10.1093/treephys/tpp018

Casasoli M, Derory J, Morera-Dutrey C, Brendel O, Porth I, Guehl J, Villani F, Kremer A (2006) Comparison of quantitative trait loci for adaptive traits between oak and chestnut based on an expressed sequence tag consensus map. Genetics 172:533-546.

https://dx.doi.org/10.1534/genetics.105.048439
Caswell TA, Droettboom M, Lee A, de Andrade ES, Hunter J, Hoffmann T, Ivanov P (2021) matplotlib/matplotlib: REL: v3.4.1 (Version v3.4.1). Zenodo. http://doi.org/10.5281/zenodo.4649959.

Čehulić I, Sever K, Katičić Bogdan I, Jazbec A, Škvorc Ž, Bogdan S (2019) Drought impact on leaf phenology and spring frost susceptibility in a Quercus robur L. provenance trial. Forests, 10(1), 50. https://dx.doi.org/10.3390/f10010050 Chung S, Parish RW (2008) Combinatorial interactions of multiple cis-elements regulating the induction of the Arabidopsis XERO2 dehydrin gene by abscisic acid and cold. Plant Journal 54(1):15-29. https://doi.org/10.1111/j.1365-313x.2007.03399.x

Derory J, Scotti-Saintagne C, Bertocchi E, Le Dantec L, Graignic N, Jauffres A, Casasoli M, Chancerel E, Bodenes C, Alberto F, Kremer A (2010) Contrasting relations between diversity of candidate genes and variation of bud burst in natural and segregating populations of European oaks. Heredity 105(4):401-11. https://dx.doi.org/10.1038/hdy.2009.170

Dubravac T, Dekanić S, Roth V (2011) Dinamika oštećenosti i struktura krošanja stabala hrasta lužnjaka u šumskim zajednicama na gredi i u nizi - rezultati motrenja na trajnim pokusnim plohama. Šumarski list - posebni broj: 74-89.

Ducousso A, Bordacs S (2003) EUFORGEN Technical Guidelines for genetic conservation and use for Pedunculate and sessile oaks (Quercus robur) and (Quercus petraea). Bioversity International.

Durand J, Bodénès $C$, Chancerel E, Frigerio J, Vendramin G, Sebastiani F, Buanamici A, Gailing O, Koelewijn H, Villani F, Mattioni C, Cherubini M, Goicoechea PG, Herran A, Ikaran Z, Cabané C, Ueno S, Alberto F, Dumoulin P, Guichoux E, de Daruvar A, Kremer A, Plomion C (2010) A fast and cost-effective approach to develop and map EST-SSR markers: oak as a case study. BMC Genomics 11:570. https://dx.doi.org/10.1186/1471-2164-11-570

Dure L, Greenway SC, Galau GA (1981) Developmental biochemistry of cotton seed embryogenesis and germination: changing messenger ribonucleic acid populations as shown by in vitro and in vivo protein synthesis. Biochemistry 20:4162-4168.

Temperate oaks and beech network (2003) EUFORGEN [online]. Available < http://www.ipgri.cgiar.org/networks/enforgen $>$ [cited 12.07.2021.].

Hirano H (2021) Basic 7S globulin in plants. Journal of Proteomics 104209. https://doi.org/10.1016/j.jprot.2021.104209.

Hsing YIC, Chen ZY, Chow TY (1995) A soybean cDNA (accesssion No. L20806) encoding a hydrophobic embryogenesis abundant protein. Plant Physiology 109: 1125-1127

Porth I, Koch M, Berenyi M, Burg A, Burg K (2005) Identification of adaptation-specific differences in mRNA expression of sessile and pedunculate oak based on osmotic-stress-induced genes. Tree Physiology 25: 1317-1329. https://dx.doi.org/10.1093/treephys/25.10.1317

IPCC, 2021: Climate Change 2021: The Physical Science Basis. Contribution of Working Group I to the Sixth Assessment Report of the Intergovernmental Panel on Climate Change [Masson-Delmotte V, Zhai P, Pirani A, Connors SL, Péan C, Berger S, Caud N, Chen Y, Goldfarb L, Gomis MI, Huang M, Leitzell K, Lonnoy E, Matthews JBR, Maycock TK, Waterfield T, Yelekçi O, Yu R and Zhou $B$ (eds.)]. Cambridge University Press. In Press.

Vandesompele J, De Preterm K, Pattyn F, Poppe B, Van Roy N, De Paepe A, Speleman $F$ (2002) Accurate normalization of real-time quantitative RT-PCR data by geometric averaging of multiple internal control genes. Genome Biology 3.7: 1-12. https://dx.doi.org/10.1186/gb-2002-3-7-research0034

Kotrade P, Sehr EM, Wischnitzki E, Brüggemann W (2019) Comparative transcriptomics-based selection of suitable reference genes for normalization of RT-qPCR experiments in drought-stressed leaves of three European Quercus species. Tree Genetics \& Genomes 15(3), 1-12. https://dx.doi.org/10.1007/s11295-019-1347-4

Le Provost G, Herrera R, Ap Paiva J, Chaumeil P, Salin F, Plomion C (2007) A micromethod for high throughput RNA extraction in forest trees. Biol Research 40:291-297. doi:10.4067/S0716-97602007000400003

Le Provost G, Lesur I, Lalanne C, Da Silva C, Labadie K, Aury JM, Plomion C (2016) Implication of the suberin pathway in adaptation to waterlogging and hypertrophied lenticels formation in pedunculate oak (Quercus robur L.). Tree physiology 36(11), 1330-1342. https://dx.doi.org/10.1093/treephys/tpw056

Leroy T, Louvet JM, Lalanne C, Le Provost G, Labadie K, Aury JM, Delzon S, Plomion C, Kremer A (2020) Adaptive introgression as a driver of local adaptation to climate in European white oaks. New Phytologist 226: 1171-1182. https://dx.doi.org/10.1111/nph.16095 
Magalhães AP, Verde N, Reis F, Martins I, Costa D, Lino-Neto T, Castro PH, Tavares RM, Azevedo H (2016) RNA-Seq and gene network analysis uncover activation of an ABA-dependent signalosome during the cork oak root response to drought. Frontiers in Plant Science 6:1195. https://dx.doi.org/10.3389/fpls.2015.01195

Manzoni S (2014) Integrating plant hydraulics and gas exchange along the drought-response trait spectrum. Tree Physiology 34(10): 1031-1034. https://dx.doi.org/10.1093/treephys/tpu088

Metzger MJ, Bunce RGH, Jongman RHG, Mücher CA and Watkins JW (2005) A climatic stratification of the environment of Europe. Global Ecology and Biogeography 14: 549-563. https://doi.org/10.1111/j.1466-822X.2005.00190.x

Miller JD, Arteca RN, Pell EJ (1999) Senescence-associated gene expression during ozone-induced leaf senescence in Arabidopsis. Plant Physiology 120(4):1015-24. doi: 10.1104/pp.120.4.1015.

Murray SL, Ingle RA, Petersen LN, Denby KJ (2007) Basal resistance against Pseudomonas syringae in Arabidopsis involves WRKY53 and a protein with homology to a nematode resistance protein. Molecular Plant-Microbe Interaction 20(11):1431-8. doi: 10.1094/MPMI-20-11-1431

Spies N, Oufir M, Matusikova I, Stierschneider M, Kopecky D, Homolka A, Burg K, Fluch S, Hausman JF, Wilhelm E (2012) Ecophysiological and transcriptomic responses of oak (Quercus robur) to long-term drought exposure and rewatering. Environmental and Experimental Botany 77: 117- 126. https://dx.doi.org/10.1016/j.envexpbot.2011.11.010

Pilipović A, Drekić M, Stojnić S, Nikolić N, Trudić B, Milović M, Poljaković-Pajnik L, Borišev M, Orlović S (2020) Physiological Responses of Two Pedunculate Oak (Quercus robur L.) Families to Combined Stress Conditions - Drought And Herbivore Attack. Šumarski list 144 (11-12):5. https://doi.org/10.31298/sl.144.11-12.5

Plomion C, Aury JM, Amselem J, Leroy T, Murat F, Duplessis S, Faye S, Francillonne N, Labadie K, Le Provost G et al. (2018) Oak genome reveals facets of long lifespan. Nature Plants 4: 440-452. https://dx.doi.org/10.1038/s41477-018-0172-3

Ponton S, Dupouey J, Bréda N, Dreyer E (2002) Comparison of water-use efficiency of seedlings from two sympatric oak species: genotype $\times$ environment interactions. Tree Physiology 22(6): 413-422. https://dx.doi.org/10.1093/treephys/22.6.413

Rađević V, Pap P, Vasić V (2020) Management of the common oak forests in Ravni Srem: Yesterday, today, tomorrow. Topola (206): 41-52.

Roussel M, Le Thiec D, Montpied P, Ningre N, Guehl J, Brendel O (2009) Diversity of water use efficiency among Quercus robur genotypes: contribution of related leaf traits. Annals of Forest Science 66: 408 https://dx.doi.org/10.1051/forest/2009010

Rozen S, Skaletsky H (2000) Primer3 on the WWW for general users and for biologist programmers. Methods in Molecular Biology 132:365-86. https://dx.doi.org/10.1385/1-59259-192-2:365

Stojanović D, Levanič T, Matović B, Bravo-Oviedo A (2015) Climate change impact on a mixed lowland oak stand in Serbia. Annals of Silvicultural Research 39(2): 94-99. https://dx.doi.org/10.12899/ASR-1126

Stojnić S, Kovačević B, Kebert M, Vaštag, E, Bojović M, Stanković-Neđić, M, Orlović S (2019a) The use of physiological, biochemical and morpho-anatomical traits in tree breeding for improved water-use efficiency of Quercus robur L. Forest Systems 28(3): e017. https://doi.org/10.5424/fs/2019283-15233

Stojnić S, Orlović, S, Pilipović A (2019b) Ex situ conservation of forest genetic resources in Serbia. In: Šijačić-Nikolić, M., Milovanović, J., Nonić, M. (Eds.). Forests of Southeast Europe under a changing climate. Conservation of forest genetic resources. Springer Nature Switzerland AG, pp. 227-237

The Arabidopsis Information Resource (2015) Making and mining the "gold standard" annotated reference plant genome. genesis doi: 10.1002/ dvg.22877

Thierry-Mieg D, Thierry-Mieg J (2006) AceView: a comprehensive cDNA-supported gene and transcripts annotation. Genome Biology 7: S12. https://doi.org/10.1186/gb-2006-7-s1-s12

Torre S, Tattini M, Brunetti C, Fineschi S, Fini A, Ferrini F, Sebastiani F (2014) RNAseq analysis of Quercus pubescens leaves: de novo transcriptome assembly, annotation and functional markers development. PLoS One 9(11): e112487. https://dx.doi.org/10.1371/journal.pone.0112487

Trudić B, Avramidou E, Fussi B, Neophytou C, Stojnić S, Pilipović P (2021) Conservation of Quercus robur $L$. genetic resources in its south-eastern refugium using SSR marker system - a case study from Vojvodina province, Serbia. Austrian Journal of Forest Science 138 (2): 117-140.

Trudić B, Radović S, Galović V, Jovanović Ž, Stanisavljević N (2012) Molekularni mehanzimi odgovora drvenastih vrsta biljaka na abiotički stres. Topola 189/190: 67-86.

Trudić B, Galović V, Orlović S, Pap P, Pekeč S (2013) A strategy for the identifcation of a candidate gene for drought induced stress in pedunculate oak (Quercus robur I. (Q. pedunculata Ehrh.)), Fagaceae. Bulgarian Journal of Ag ricultural. Sciences 19: 338-346.

Ueno S, Le Provost G, Léger V, Klopp C, Noirot C, Frigerio J, Salin F, Salse J, Abrouk M, Murat F, Brendel O, Derory J, Abadie P, Léger P, Cabane C, Barré A, de Daruvar A, Couloux A, Wincker P, Reviron M, Kremer A, Plomion C (2010) Bioinformatic analysis of Sanger and 454 ESTs for a keystone forest tree species: oak. BMC Genomics 11:650-674.

Varela MC (1995) Consevation of genetic resources of Quercus suber in Portugal. In: European Forest Resources Programme (EUFORGEN).

Voelker S, Meinzer F, Lachenbruch B, Brooks R, Guyette R (2014) Drivers of radia growth and carbon isotope discrimination of bur oak (Quercus macrocarpa Michx.) across continental gradients in precipitation, vapour pressure deficit and irradiance. Plant, Cell and Environment 37.3: 766-779. doi: 10.1111/pce.12196

Wagner U, Edwards R, Dixon DP, Mauch F (2002) Probing the diversity of the Arabidopsis glutathione S-transferase gene family. Plant Molecular Biology 49(5):515-32. doi: 10.1023/a:1015557300450.

Yamaguchi-Shinozaki K, Shinozaki K (1993) The plant hormone abscisic acid mediates the drought-induced expression but not the seed-specific expression of rd22, a gene responsive to dehydration stress in Arabidopsis thaliana. Molecular and General Genetics 238(1-2):17-25. doi: 10.1007/BF00279525. 